\title{
Prostate Large Cell Neuroendocrine
}

\section{Carcinoma}

National Cancer Institute

\section{Source}

National Cancer Institute. Prostate Large Cell Neuroendocrine Carcinoma. NCI

Thesaurus. Code C158650.

An exceptionally rare neuroendocrine carcinoma that arises from the prostate gland. It is characterized by the presence of malignant large cells. 